\title{
QUANTITATIVE STUDIES ON COMPETITIVE ACTIVITIES OF SKIN BACTERIA GROWING ON SOLID MEDIA
}

\author{
RaJAa M. MiLyani and S. SELWyN \\ Department of Microbiology, Westminster Medical School, London SWI \\ Plate XXXVI
}

INTERACTIONS among skin micro-organisms have begun to receive attention in recent years, but detailed quantitative work has apparently been restricted to growth studies in liquid media (Marsh and Selwyn, 1977). However, such culture systems bear little or no relationship to the skin surface. As a first step towards a more realistic approach, we have devised a quantitative method to study pure and mixed cultures growing on the surface of agar media, and experiments were carried out on antagonistic activities between skin bacteria by means of this procedure. The method, and representative results obtained with it, are described in this paper.

\section{MATERIALS AND METHODS}

Bacterial strains. The three commensal organisms used were an antibiotic-producing strain of Staphylococcus epidermidis biotype 4 (Baird-Parker, 1974) referred to as $\mathrm{S6}^{+}$, a penicillin-resistant non-antibiotic-producing strain of Staph. epidermidis of biotype 4 referred to as $\mathrm{S6}^{-}$, a strain of Micrococcus sp. classified as M7 according to Baird-Parker (1965), and a group-D diphtheroid strain (Evans, 1968). These were all isolated from normal skin. The three pathogenic organisms used were a penicillin-resistant strain of Staphylococcus aureus (bacteriophage group III) and a strain of Streptococcus pyogenes, both from infected skin lesions, and a strain of Corynebacterium diphtheriae var. mitis from a stock culture. The Staph. aureus strain showed relatively small inhibition zones in direct antagonism tests with $\mathrm{S}^{+}{ }^{+}$when compared with all but one of the other bacteria studied. The exception was the non-antibiotic-producing strain, $\mathrm{S6}^{-}$, which was totally resistant to the action of $\mathrm{S}^{+}$ (Marsh and Selwyn, 1977).

Media. Nutrient agar and blood agar were used as growth media, and stock cultures were kept in nutrient broth at $4^{\circ} \mathrm{C}$. The media were prepared as described by Cruickshank (1965) with Proteose Peptone and Lab-Lemco (Oxoid), New Zealand Agar and Defibrinated Horse Blood (Tissue Culture Services), and, in addition, $0.3 \%$ (w/v) Liver Digest and $0.3 \%$ (w/v) Yeast Extract (Oxoid). The selective media devised by Marsh and Selwyn (1977) made it possible to obtain differential counts of the bacteria in mixtures (table $\mathrm{I}$ ).

Sampling method. The quantitative study of bacteria growing on a solid surface was carried out with special Petri dishes (Sterilin, code 504 S) which were originally designed for direct contact culture of contaminated surfaces. Each dish had a surface area of $24 \mathrm{~cm}^{2}$ and a grid divided into centimetre squares.

The inoculum was prepared by diluting a $24-\mathrm{h}$ culture to give approximately $10^{\circ}$ colonyforming units (c.f.u.) per ml. For pure culture studies, a $0 \cdot 2-\mathrm{ml}$ volume was placed on the surface of the medium after it had dried for $20 \mathrm{~min}$. Each plate was gently rotated to distribute the inoculum evenly over the surface $\left(8 \times 10^{3}\right.$ c.f.u. per $\left.\mathrm{cm}^{2}\right)$. In mixed-culture studies, $1-\mathrm{ml}$ volumes containing $1 \times 10^{8}$ c.f.u. of each strain were mixed and $0.2 \mathrm{ml}$ of the mixture was used as the inoculum. Readings of viable counts taken at intervals permitted the construction of growth curves from the mean results of three plates.

Received 5 Aug. 1977; revised version accepted 5 Nov. 1977.

J. MED. MICROBIOL.-VOL. 11 (1978) 
TABLE I

Summary of viable counts in mixed cultures on solid media

\begin{tabular}{|c|c|c|c|c|c|}
\hline \multirow{2}{*}{$\begin{array}{l}\text { Organisms present in } \\
\text { mixed cultures }\end{array}$} & \multirow{2}{*}{$\begin{array}{l}\text { Growth } \\
\text { medium }\end{array}$} & \multirow{2}{*}{$\begin{array}{l}\text { Selective } \\
\text { medium }\end{array}$} & \multicolumn{3}{|c|}{$\begin{array}{l}\log _{10} \text { viable count } \\
\text { (c.f.u. per } \mathrm{cm}^{2} \text { ) at }\end{array}$} \\
\hline & & & $0.25 \mathrm{~h}$ & $12 \mathrm{~h}$ & $28 \mathrm{~h}$ \\
\hline$\left\{\begin{array}{l}\text { S6- } \\
\text { M7 }\end{array}\right.$ & NA & $\begin{array}{l}\mathbf{N A}+\mathbf{B}+\mathbf{P} \\
\mathbf{N A}+\mathbf{F}+\mathbf{K}\end{array}$ & $\begin{array}{l}3 \cdot 4 \\
4 \cdot 5\end{array}$ & $\begin{array}{l}9 \cdot 4 \\
8 \cdot 4\end{array}$ & $\begin{array}{l}9 \cdot 4 \\
9 \cdot 0\end{array}$ \\
\hline$\left\{\begin{array}{l}\text { S6+ } \\
\text { M7 }\end{array}\right.$ & NA & $\begin{array}{l}\mathbf{N A}+\mathbf{B} \\
\mathbf{N A}+\mathbf{F}\end{array}$ & $\begin{array}{l}3 \cdot 9 \\
3 \cdot 4\end{array}$ & $\begin{array}{l}9.8 \\
5 \cdot 8\end{array}$ & $\begin{array}{l}9 \cdot 8 \\
3 \cdot 8\end{array}$ \\
\hline$\left\{\begin{array}{l}\text { S6 } \\
\text { Group-D diphtheroid }\end{array}\right.$ & NA & $\begin{array}{l}\mathrm{NA}+\mathrm{B} \\
\mathrm{NA}+\mathrm{F}\end{array}$ & $\begin{array}{l}4 \cdot 5 \\
4 \cdot 2\end{array}$ & $\begin{array}{r}10 \cdot 1 \\
5 \cdot 1\end{array}$ & $\begin{array}{r}9.8 \\
0\end{array}$ \\
\hline$\left\{\begin{array}{l}\mathrm{S}^{+} \\
\text {C. diphtheriae }\end{array}\right.$ & BA & $\begin{array}{l}\mathrm{NA}+\mathrm{B} \\
\text { Tell. }\end{array}$ & $\begin{array}{r}4.4 \\
<3.0\end{array}$ & $\begin{array}{r}10 \cdot 1 \\
6 \cdot 3\end{array}$ & $\begin{array}{r}10 \cdot 3 \\
0\end{array}$ \\
\hline$\left\{\begin{array}{l}\mathrm{S}^{+} \\
\text {Strep. pyogenes }\end{array}\right.$ & BA & $\begin{array}{l}\mathrm{MacC} . \\
\mathrm{BA}+\mathrm{CV}\end{array}$ & $\begin{array}{l}4 \cdot 5 \\
3 \cdot 4\end{array}$ & $\begin{array}{r}10 \cdot 0 \\
6 \cdot 2\end{array}$ & $\begin{array}{r}9 \cdot 8 \\
0\end{array}$ \\
\hline$\left\{\begin{array}{l}\text { S6 } 6^{+} \\
\text {Staph. aureus }\end{array}\right.$ & NA & $\begin{array}{l}\text { NA } \\
\text { NA+G }\end{array}$ & $\begin{array}{l}4 \cdot 9 \\
4 \cdot 4\end{array}$ & $\begin{array}{r}10.8 \\
9.9\end{array}$ & $\begin{array}{l}10 \cdot 3 \\
10 \cdot 3\end{array}$ \\
\hline
\end{tabular}

c.f.u. = Colony-forming units.

$\mathrm{NA}=$ Nutrient agar; $\mathrm{BA}=$ blood agar; $\mathrm{B}=$ bacitracin $(1.25 \mathrm{mg}$ per litre); $\mathrm{P}=$ benzylpenicillin ( $0.1 \mathrm{mg}$ per litre); $\mathrm{F}=$ furazolidone ( $7.5 \mathrm{mg}$ per litre); $\mathrm{K}=$ kanamycin ( $0.156 \mathrm{mg}$ per litre); Tell. = tellurite agar; MacC. $=$ MacConkey's agar; $C V=$ crystal violet $(1$ in $666666, \mathrm{w} / \mathrm{v})$; $\mathbf{G}=$ benzylpenicillin ( $3 \mathrm{mg}$ per litre).

Viable counts were obtained by cutting a centimetre square of agar from each inoculated plate by means of a sterile disposable scalpel (fig. 1). These squares were then transferred to a sterile screw-capped container, and washed with $5 \mathrm{ml}$ of $0.05 \%$ Triton X-100 in $0.0375 \mathrm{M}$ phosphate buffer, $p$ H 7.9 (B.D.H. Chemicals Ltd); this efficiently washed organisms from the surface of the plates, and large clusters of bacterial cells were dispersed by subjecting the resulting suspension to mechanical agitation in a Rotamixer. To ensure the removal of the greatest possible number of bacteria, the surfaces of the squares immersed in dispersing fluid were scraped with a scalpel before agitating the container. Viable counts were derived from. this suspension by the method of Miles, Misra and Irwin (1938), with 1 -strength Ringer's solution as diluent.

When assessing the reproducibility of the method, 10 replicate cultures were sampled in strict sequence. The sampling procedure was not sensitive enough for the accurate determination of viable counts below $10^{3}$ c.f.u. per $\mathrm{cm}^{2}$. Below this level, however, the presence or absence of significant numbers of bacteria was established by homogenising the agar squares in dispersing fluid. All the fluid from the homogenate was then passed through a Millipore filter $(0.45-\mu \mathrm{m}$ porosity), after which the bacteria on the filter disk were cultured on the appropriate media.

The numbers of residual bacteria were estimated in representative instances by sampling several squares in parallel from a single plate. After rinsing gently in dispersing fluid, the squares were pooled together, mixed with an equal volume of fresh dispersing fluid, and homogenised. The fluid was harvested as completely as possible, and viable counts were determined as above.

Studies of interactions. The qualitative techniques adopted were those described by Marsh and Selwyn (1977). The quantitative studies were carried out as described above. Each strain was grown and studied in pure culture. Mixed cultures were then studied under 
similar conditions, and growth curves were constructed. All the cultures described were incubated at $37^{\circ} \mathrm{C}$, but a number of experiments were duplicated at $33^{\circ} \mathrm{C}$ and no significant difference was noted.

\section{Results}

Reproducibility of the method. Table II shows the range of viable counts and statistical data for the staphylococcal strain $\mathrm{S}^{+}$growing on nutrient agar plates after simultaneous inoculation with $8 \times 10^{3}$ c.f.u. per $\mathrm{cm}^{2}$. The viable counts of the first three plates in the series of ten showed remarkable uniformity, varying only by a maximum of $0 \cdot 25$ of a logarithm.

The proportion of the culture not liberated from the agar was found to be negligible. It was less than $0.1 \%$ of the total calculated from the initial viable count when the population was greater than $10^{5} \mathrm{c}$.f.u. per $\mathrm{cm}^{2}$, and was between

TABLE II

Variability of the viable counts of the staphylococcal strain $\mathrm{S6}^{+}$obtained by the quantitative solid surface method

\begin{tabular}{c|ccccc}
\hline $\begin{array}{c}\text { Time } \\
(\mathrm{h})\end{array}$ & $\begin{array}{c}\text { Number of } \\
\text { plates }\end{array}$ & $\begin{array}{c}\text { Mean } \log _{10} \\
\text { viable } \\
\text { count }\end{array}$ & $\begin{array}{c}\text { Range of } \\
\text { counts } \\
\left(\log _{10}\right)\end{array}$ & $\begin{array}{c}\text { Standard } \\
\text { deviation } \\
\text { (SD) }\end{array}$ & $\begin{array}{c}\text { Standard } \\
\text { error }\end{array}$ \\
\hline 1 & All 10 & 4.24 & $4.00-4.40$ & 0.148 & 0.047 \\
& First 3 & 4.09 & $4 \cdot 00-4.18$ & 0.090 & 0.052 \\
7 & All 10 & 7.92 & $7.62-8.19$ & 0.195 & 0.062 \\
& First 3 & 7.70 & $7.62-7.79$ & 0.086 & 0.050 \\
& All 10 & 9.13 & $8.87-9.44$ & 0.207 & 0.065 \\
& First 3 & 9.04 & $8 \cdot 87-9.14$ & 0.146 & 0.084
\end{tabular}

TABLE III

Summary of mixed-culture results for the antibiotic-producing staphylococcal strain $\mathrm{S6}^{+}$and Staph. aureus on nutrient agar with inocula of different sizes

\begin{tabular}{|c|c|c|c|c|c|}
\hline \multirow{2}{*}{$\begin{array}{c}\text { Time } \\
\text { (h) }\end{array}$} & \multirow{2}{*}{ Organisms } & \multicolumn{4}{|c|}{$\begin{array}{c}\text { Mean } \log _{10} \text { viable counts (c.f.u. per } \mathrm{cm}^{2} \text { ) } \\
\text { in experiment }\end{array}$} \\
\hline & & A & B & C & D \\
\hline 0 & $\begin{array}{l}\text { S6 }^{+} \\
\text {Staph. aureus }\end{array}$ & $\begin{array}{l}4 \cdot 9 \\
4 \cdot 4\end{array}$ & $\begin{array}{l}6 \cdot 3 \\
5 \cdot 6\end{array}$ & $\begin{array}{l}7 \cdot 2 \\
3 \cdot 8\end{array}$ & $\begin{array}{r}4 \cdot 0 \\
<3 \cdot 0\end{array}$ \\
\hline 12 & $\begin{array}{l}\text { S6 }^{+} \\
\text {Staph. aureus }\end{array}$ & $\begin{array}{r}10 \cdot 8 \\
9 \cdot 9\end{array}$ & $\begin{array}{r}10 \cdot 1 \\
7 \cdot 6\end{array}$ & $\begin{array}{r}10 \cdot 2 \\
4 \cdot 0\end{array}$ & $\begin{array}{l}9.9 \\
8 \cdot 0\end{array}$ \\
\hline 24 & $\begin{array}{l}\text { S6 }^{+} \\
\text {Staph. aureus }\end{array}$ & $\begin{array}{l}10 \cdot 7 \\
10 \cdot 3\end{array}$ & $\begin{array}{r}10 \cdot 0 \\
5 \cdot 4\end{array}$ & $\begin{array}{r}10 \cdot 1 \\
0\end{array}$ & $\begin{array}{r}10 \cdot 1 \\
7 \cdot 8\end{array}$ \\
\hline 72 & $\begin{array}{l}\text { S6 }{ }^{+} \\
\text {Staph. aureus }\end{array}$ & $\begin{array}{r}10 \cdot 2 \\
9.6\end{array}$ & $\begin{array}{r}10 \cdot 0 \\
5.0\end{array}$ & $\begin{array}{r}10.0 \\
0\end{array}$ & $\begin{array}{l}9 \cdot 3 \\
7.8\end{array}$ \\
\hline
\end{tabular}


0.1 and $0.2 \%$ when the initial count was between $10^{4}$ and $10^{5}$. The proportion of residual organisms rose to approximately $1 \%$ when the initial count was between $10^{3}$ and $10^{4}$ c.f.u. per $\mathrm{cm}^{2}$.

Bacterial antagonism. The results are summarised in tables I and III. When $\mathrm{S}^{-}$was mixed with $\mathrm{M} 7$ on nutrient agar, no inhibitory effect was produced, but when $\mathrm{S}^{+}{ }^{+}$was mixed with $\mathrm{M} 7$ on the same medium, M7 was antagonised and its viable count fell by more than six logarithms (fig. 2). $\mathrm{S6}^{+}$showed an even stronger inhibitory effect when it was cultured with comparable inocula of the group-D diphtheroid, $C$. diphtheriae var. mitis or of the group-A streptococcus. These strains were completely inhibited within approximately $15 \mathrm{~h}$. As a typical example of this unequivocal effect, fig. 3 shows the results obtained with Strep. pyogenes.

In contrast, as shown in table III and, in greater detail, in figs. 4 and 5 , the outcome of interaction between $\mathrm{S}^{+}$and Staph. aureus depended on the initial inoculum size of both organisms. When the two organisms were inoculated at

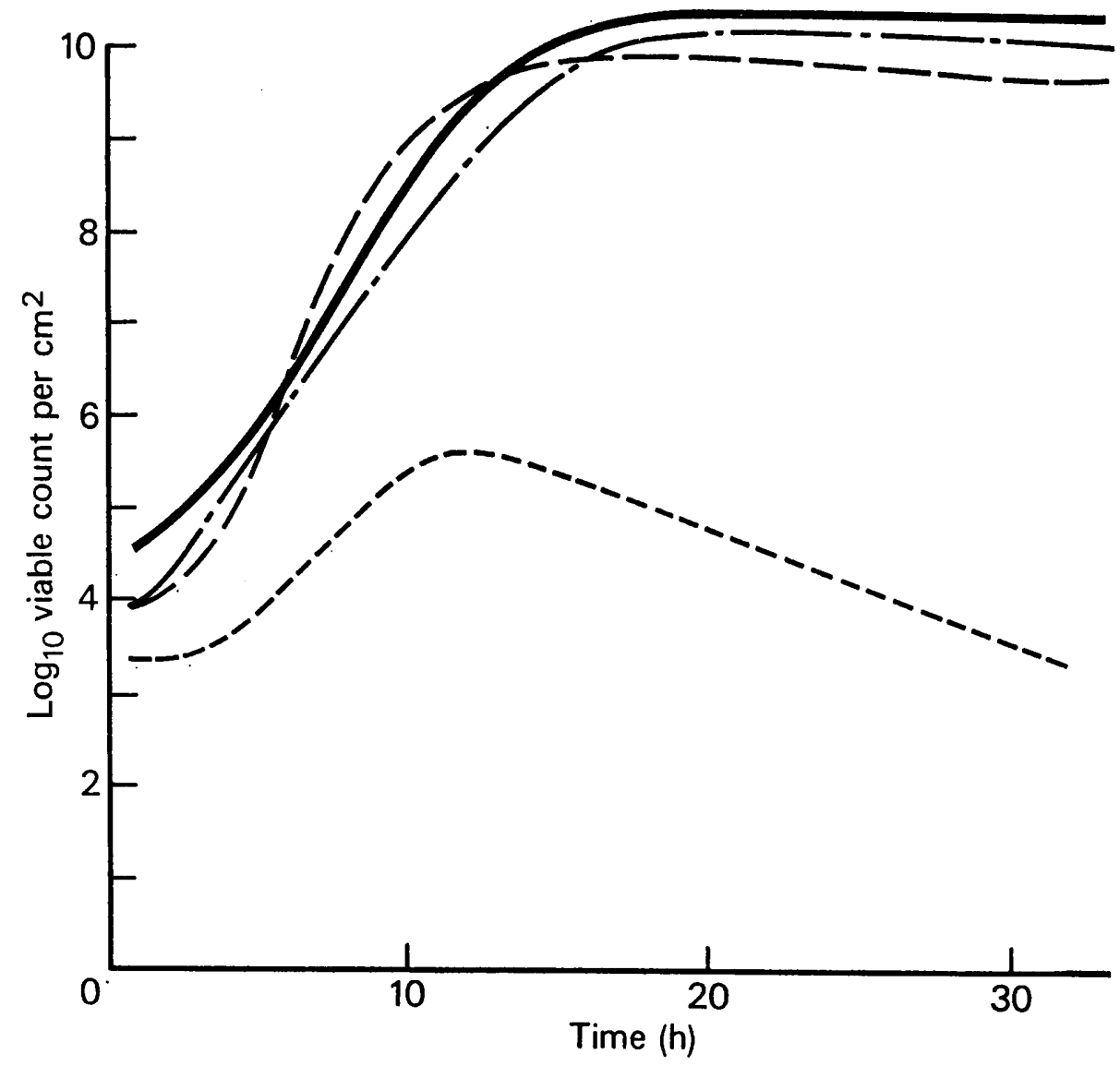

FIG. 2.-Growth curves of pure and mixed cultures of strains $S 6^{+}$and $M 7$ on nutrient agar at $37^{\circ} \mathrm{C}$. $\underline{-}=\mathrm{S} 6^{+}$(pure); $\cdots . . .=\mathrm{M} 7$ (pure); $-=\mathrm{S}^{+}$(mixed); $-\cdots=\mathrm{M} 7$ (mixed). 


\section{COMPETITIVE ACTIVITIES OF SKIN BACTERIA}

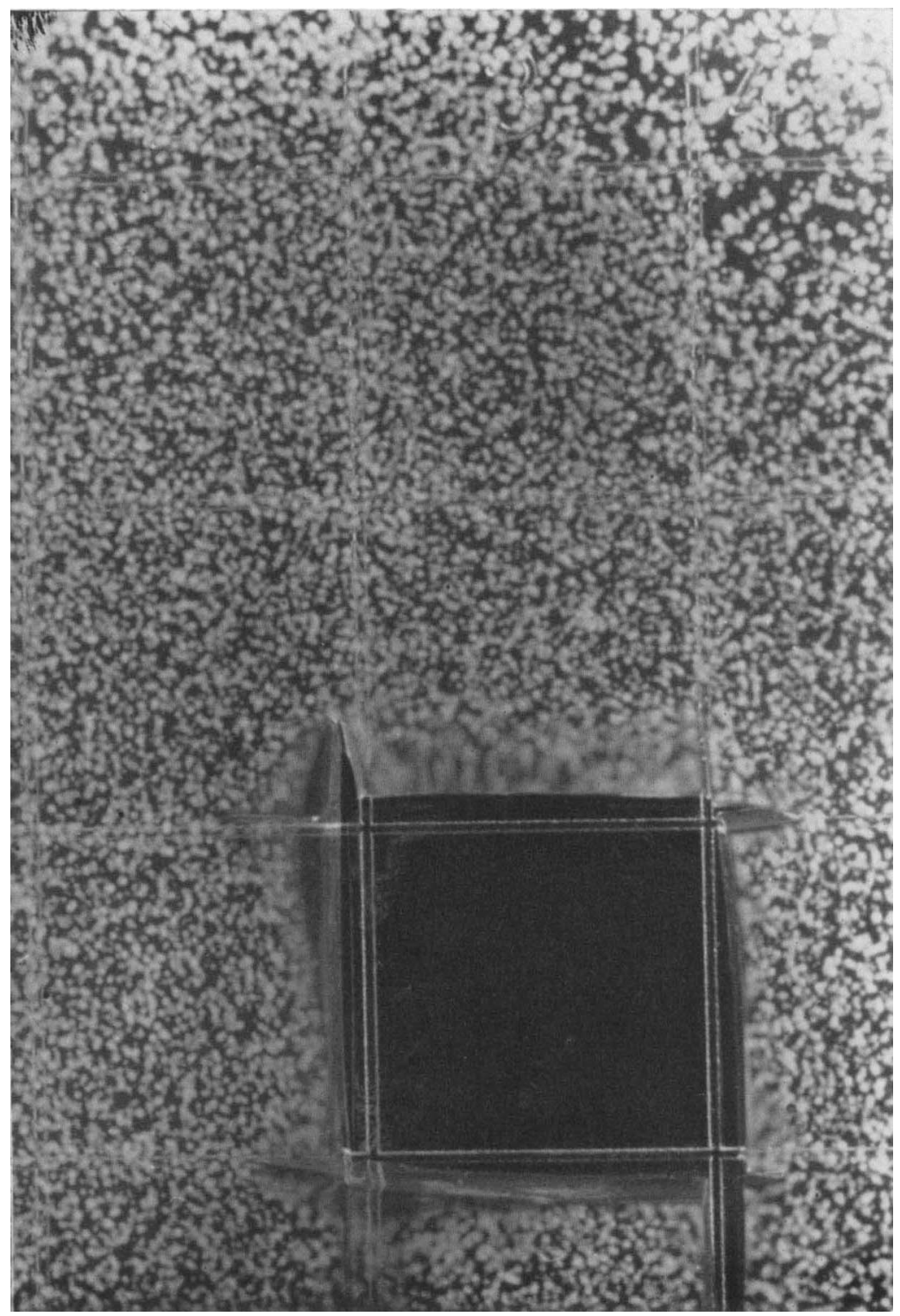

Fig. 1.-View of mixed culture of strains $\mathrm{S}^{+}$and $\mathrm{M} 7$ after incubation for $12 \mathrm{~h}$. Note retraction of agar after excision of the square. $\times 4$. 


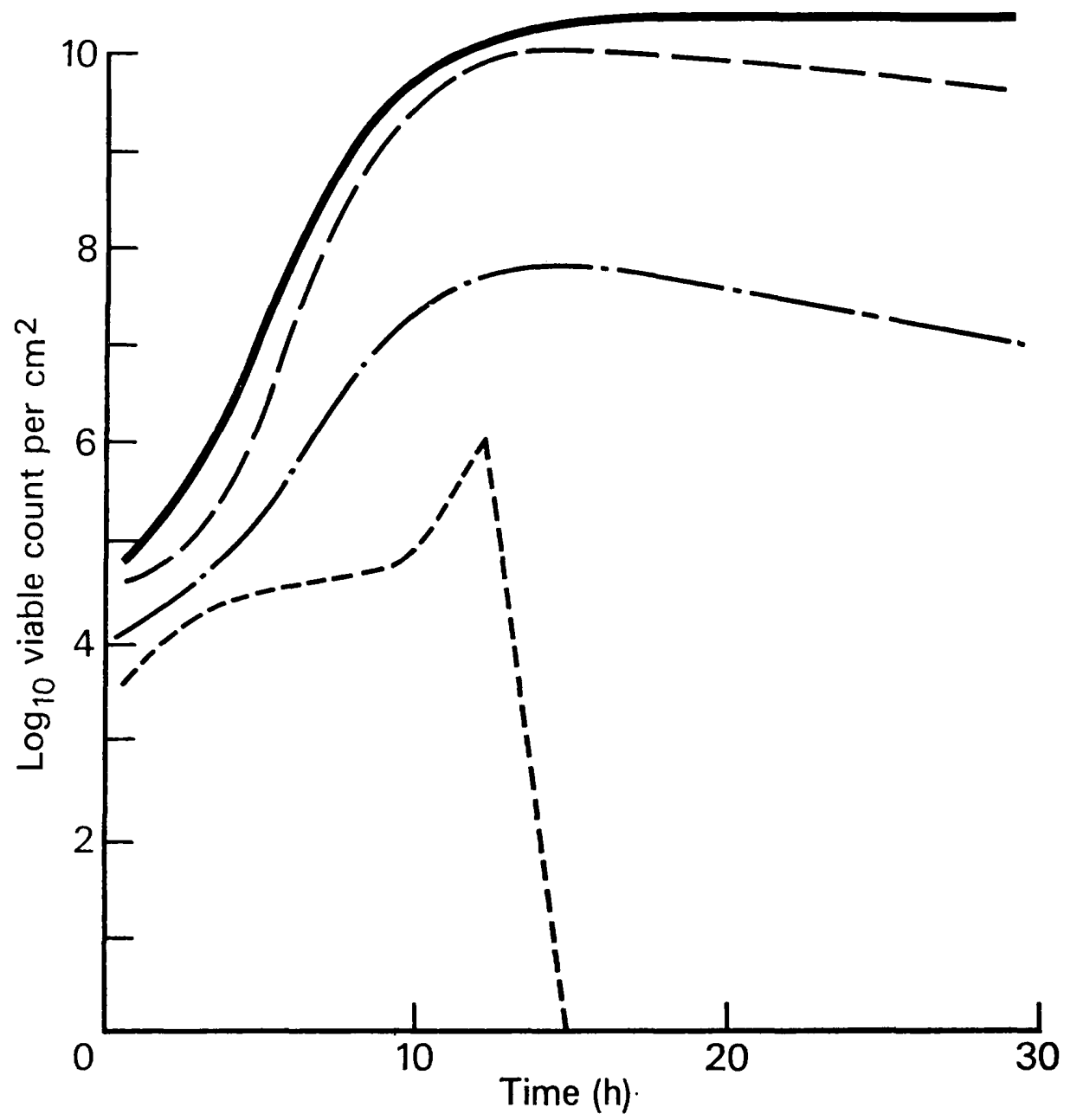

Fig. 3.-Growth curves of pure and mixed cultures of strains $\mathbf{S} 6^{+}$and Strep. pyogenes on blood agar at $37^{\circ} \mathrm{C}$. $-=\mathrm{S} 6^{+}$(pure); $---\mathrm{S} 6^{+}$(mixed); $\cdots . . .=$ Strep. pyogenes (pure); $-\cdots$ Strep. pyogenes (mixed).

the same population level Staph. aureus was not inhibited. However, when the initial inoculum of $\mathrm{S}^{+}\left(10^{6} \mathrm{c.f} . \mathrm{u}\right.$. per $\left.\mathrm{cm}^{2}\right)$ was only one logarithm higher than that of Staph. aureus, the viable count of Staph. aureus, after $60 \mathrm{~h}$, was six logarithms lower than the corresponding count in pure culture. Moreover, when the original population level of $\mathrm{S}^{+}$was 1000 -fold higher than that of Staph. aureus, the latter was completely inhibited within $24 \mathrm{~h}$. In another experiment (D), the original inoculum of $\mathrm{S}^{+}$was $10^{4}$ c.f.u. per $\mathrm{cm}^{2}$ and that of Staph. aureus was less than $10^{3}$ c.f.u. per $\mathrm{cm}^{2}$. Despite this difference, Staph. aureus had reached a viable count of $10^{8}$ c.f.u. per $\mathrm{cm}^{2}$ after incubation for $12 \mathrm{~h}$, and after a slight decline maintained a population level of $6 \times 10^{7}$ c.f.u. per $\mathrm{cm}^{2}$ for up to $72 \mathrm{~h}$. In all the experiments $\mathrm{S}^{+}$showed the same pattern of growth as in pure culture. 


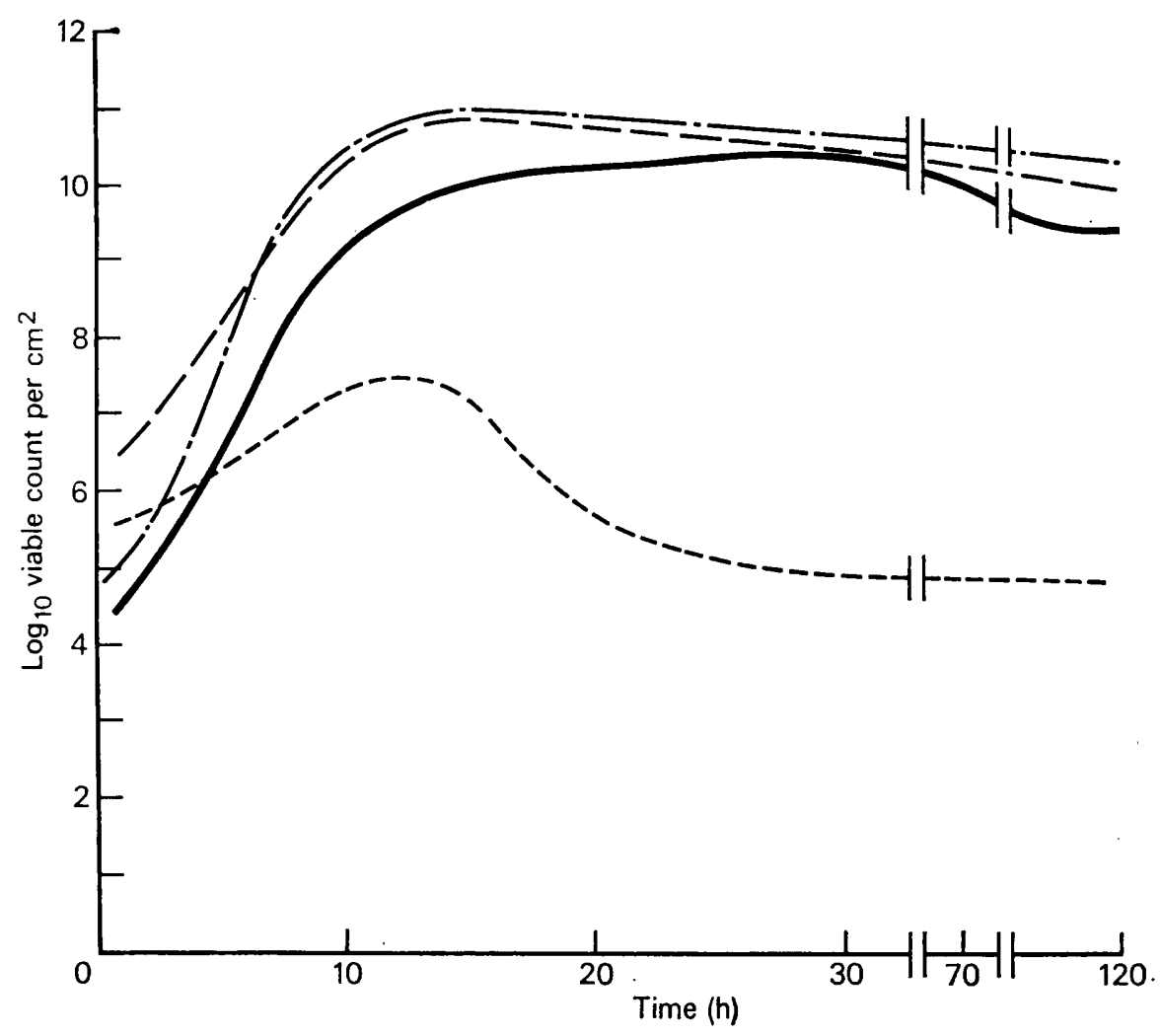

Fig. 4.- Growth curves of mixed cultures of strain $\mathrm{S6}^{+}$and Staph. aureus on nutrient agar at $37^{\circ} \mathrm{C}$ (experiments $\mathrm{A}$ and $\mathrm{B}$ ). $\ldots=\mathrm{S} 6^{+}$(mixed), experiment $\mathrm{A} ;---=\mathrm{S}^{+}$(mixed), experiment $\mathrm{B} ;-\mathrm{Ataph}$. aureus (mixed), experiment $\mathrm{A} ;---=$ Staph. aureus (mixed), experiment $\mathbf{B}$.

\section{Discussion}

The quantitative method devised, based on the use of a solid surface, was found to give reproducible results, and it provided an in-vitro model for studying the interactions of skin micro-organisms. Where more than three replicate plates were sampled, the viable counts of the earlier cultures in the set were noticeably lower than those of the later cultures, due to significant bacterial growth during the extended sampling procedure.

The inhibitory action of $\mathrm{S6}^{+}$on the strains tested on solid media was comparable to, but more pronounced than, that demonstrated in liquid media (Marsh and Selwyn, 1977). For example, in liquid medium the viable count of M7 was reduced only 300 -fold, whereas on solid medium it had decreased by almost seven logarithms. Again, in liquid media $\mathrm{S6}^{+}$was unable to inhibit C. diphtheriae var. mitis or Strep. pyogenes, but on solid media both organisms were totally inhibited and indeed killed. This may be attributable to the dilution of antibiotic as a result of its dispersal throughout the liquid culture; on solid surfaces the antibiotic is held locally in the medium in a concentration sufficiently high to reach not only bacteristatic but also bactericidal levels. 


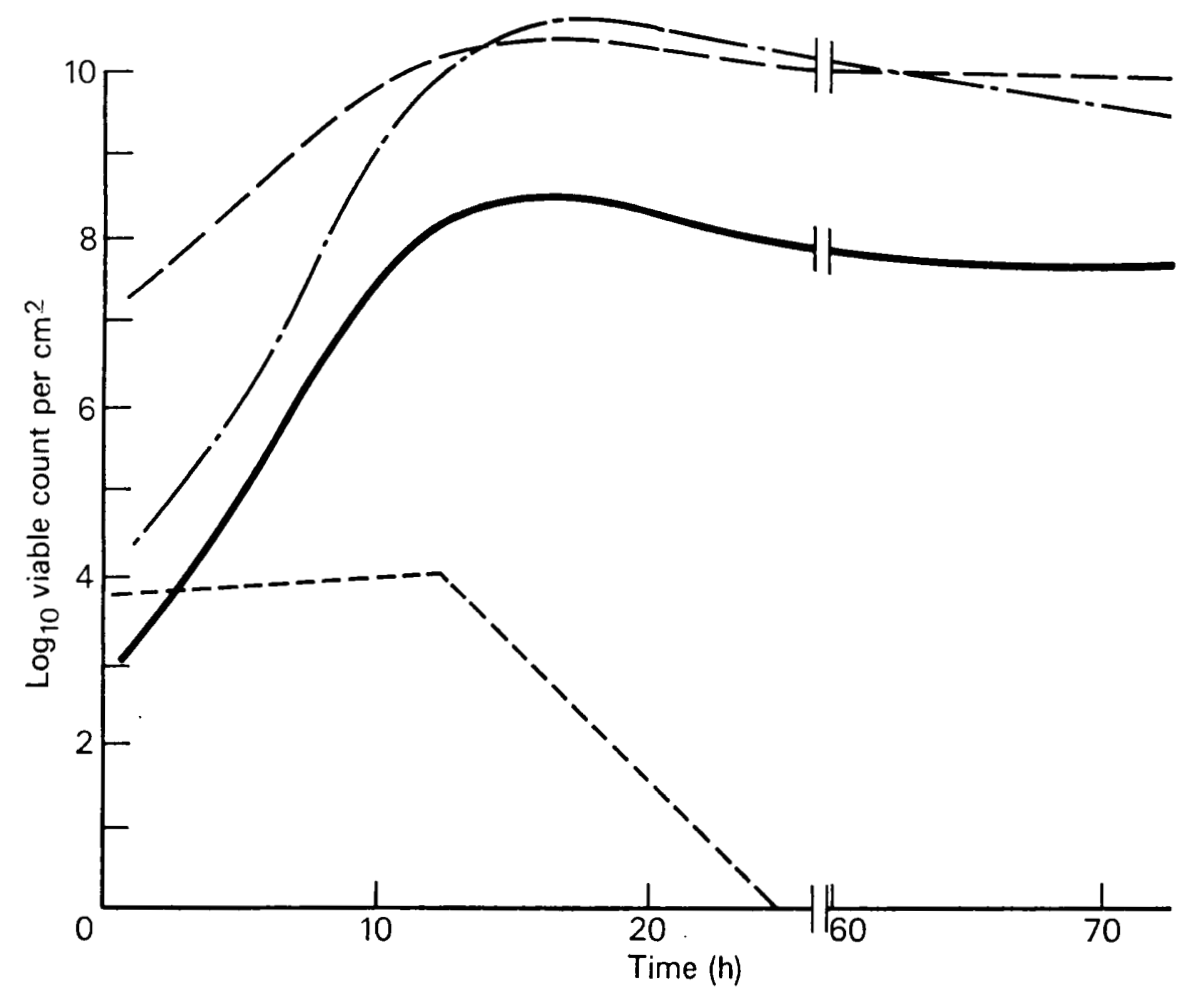

Fig. 5.-Growth curves of mixed cultures of strain $\mathrm{S}^{+}$and Staph. aureus on nutrient agar at $37^{\circ} \mathrm{C}$ (experiments $\mathbf{C}$ and $\mathrm{D}$ ). $--=\mathrm{S} 6^{+}$(mixed), experiment $\mathrm{C} ; \cdots \cdots=\mathrm{S} 6^{+}$(mixed), experiment $\mathrm{D} ; \overline{\mathrm{C}}=$ Staph. aureus (mixed), experiment $\mathrm{D} ;-\cdots=$ Staph. aureus (mixed), experiment $\mathbf{C}$.

The results obtained from experiments with mixed cultures of $\mathrm{S}^{+}$and Staph. aureus are in contrast to those obtained in conventional direct and deferred tests of antagonism, in which the zones of inhibition of the Staph. aureus strain were consistently produced by $\mathrm{S}^{+}$, although they were significantly smaller than those of, for example, the group-D diphtheroid. The lack of consistent inhibition is also in contrast to the results of in-vivo work on rabbits (T. N. Sethna, personal communication). A possible explanation of these discrepancies is the relatively large inoculum of $\mathrm{S}^{+}$used in the conventional tests for antagonism. This is confirmed by the results (table III). Clearly, $\mathrm{S}^{+}$had to be present not only in a count of at least a logarithm higher than this particular strain of Staph. aureus to inhibit it, but also at an absolute level of at least $10^{6}$ c.f.u. per $\mathrm{cm}^{2}$. Presumably, at lower population levels, insufficient antibiotic was produced in the early stages of the mixed culture to prevent the relatively resistant Staph. aureus strain from proliferating to population levels too high to be affected by $\mathrm{S}^{+}$.

A further interrelated factor to be considered, particularly in instances of relative resistance, is the spatial relationships of the two organisms seeded on the solid medium. The physical distribution of the antibiotic-producing organism is clearly all-important. At the earliest stages of micro-colony 
formation, there will be an inadequate effect of antibiotic if the producer organism is comparatively widely dispersed. At this critical stage, the second organism is then able to multiply unimpeded by any significant amount of antibiotic, as was well seen when Staph. aureus and $\mathrm{S}^{+}{ }^{+}$were mixed in relatively low numbers.

There are obvious potential applications of antagonistic skin commensals in the prevention and treatment of infections of burns, wounds and other skin lesions. The possible protective role of antibiotic-producing organisms in dermatological lesions was indicated in a recent epidemiological study (Selwyn, 1975). A limited amount of experimental work in animals has been carried out by Pryjma, Heczko and Wilburg (1972), who used Staph. epidermidis to protect against Staph. aureus infections, but no mention was made of antibiotic production. Our current work on the application of antibiotic-producing organisms both to experimental animals and human volunteers is yielding promising results in the prevention of colonisation and infection with pathogenic bacteria (unpublished experiments).

\section{SUMMARY}

Earlier quantitative investigations of antagonism between skin bacteria were based on the use of liquid cultures, but a more realistic model has now been devised, based on the use of the surfaces of solid media. Pure or mixed inocula were spread evenly over suitable agar media in Petri dishes marked out with a standard grid. Growth curves were constructed from viable counts of the surface bacteria after they had been removed from excised squares of the agar media and dispersed. The method was highly reproducible, and competitive interactions were revealed more clearly than in studies with liquid media. An antibiotic-producing strain of Staphylococcus epidermidis $\left(\mathbf{S 6}^{+}\right)$readily suppressed strains of Micrococcus, Corynebacterium and Streptococcus species. However, a Staphylococcus aureus strain which was less sensitive to the antibiotic effect of $\mathrm{S}^{+}$interacted in a complex manner, depending on the absolute and relative size of the $\mathrm{S}^{+}$inoculum.

\section{REFERENCES}

Baird-Parker, A. C. 1965. Staphylococci and their classification. Ann. N.Y. Acad. Sci., $128,4$.

BalRD-PARKer, A. C. 1974. The basis for the present classification of staphylococci and micrococci. Ann. N.Y. Acad. Sci., 236, 7.

Cruickshank, R., Duguid, J. P. and SwaIn, R. H. A. 1965. Medical microbiology, a guide to laboratory diagnosis and control of infection. 11th ed., Edinburgh, p. 743.

Evans, N. M. 1968. The classification of aerobic diphtheroids from human skin. Br.J. Derm. $80,81$.

Marsh, P. D. AND Selwyn, S. 1977. Studies on antagonism between human skin bacteria. J. med. Microbiol., 10, 161.

Miles, A. A., MisRa, S. S. AND IRWIN, J. O. 1938. The estimation of the bactericidal power of the blood. J. Hyg., Camb., 38, 732.

Pryjma, J., Heczko, P. B. AND WilbURG, J. 1972. The effect of staphylococcal antagonism on development of infection in experimental animals. Med. dośw. Mikrobiol., 24,91 (in Polish)

SELWYN, S. 1975. Natural antibiosis among skin bacteria as a primary defence against infection. Br.J. Derm., 93, 487. 